\title{
Pengaruh Beberapa Formula Pupuk Terhadap Sifat Kimia Tanah dan Hasil Tanaman Sawi Hijau (Brassica juncea L.) di Subak Tegal Lantang Kecamatan Denpasar Barat
}

\author{
MADE KRISNANDA ADI SAPUTRA, KETUT DHARMA SUSILA*), DAN \\ TATI BUDI KUSMIYARTI
}

\author{
Program Studi Agroekoteknologi Fakultas Pertanian Universitas Udayana \\ J1. PB. Sudirman Denpasar Bali 80231 \\ ${ }^{*}$ E-mail: dharmasusila75@gmail.com
}

\begin{abstract}
Effect of Some Fertilizer Formulas on Soil Chemical Properties and Yield of Green Mustard (Brassica juncea L.) in Subak Tegal Lantang, West Denpasar

District. The aims of this study is to determine the effect of several fertilizer formulas on soil chemical properties and yield of green mustard (Brassica juncea L.) in Subak Tegal Lantang, West Denpasar District. This study used a Randomized Block Design (RBD) consisting of 6 treatments including controls and repeated 4 times with a total of 24 treatment plots. Fertilization treatment consists of three types of fertilizers, namely organic fertilizer, inorganic fertilizer, and biofertilizer. The fertilizer formula tested consisted of P0 $=$ control (without fertilizer), P1 $=5$ tons of compost ha ${ }^{-1}+300 \mathrm{~kg}$ Phonska ha- $1+200 \mathrm{~kg}^{-}$Urea ha ${ }^{-1}, \mathrm{P} 2=5$ tons of compost ha ${ }^{-1}+300 \mathrm{~kg}$ Phonska ha ${ }^{-1}+200 \mathrm{~kg}$ Urea ha ${ }^{-1}+$ biofertilizer $(1 \mathrm{cc} /$ liter water $/ \mathrm{plot})$, $\mathrm{P} 3=10$ tons of compost ha ${ }^{-1}+300 \mathrm{~kg}$ Phonska ha- $1+200 \mathrm{~kg} \mathrm{Urea} \mathrm{ha}^{-1}, \mathrm{P} 4=10$ tons of compost $\mathrm{ha}^{-1}+300 \mathrm{~kg}$ Phonska ha ${ }^{-1}+200 \mathrm{~kg}$ Urea ha ${ }^{-1}+$ biofertilizer $(1 \mathrm{cc} /$ liter of water / plot $)$, P5= biofertilizer with a concentration of $1 \mathrm{cc} /$ liter of water / plot. The data from the observed parameters then analyzed statistically using analysis of variance (Anova) to determine the significance of the treatment. If it has a significant effect on the parameters observed, then it will be followed by the LSD test at the 5\% real level. The results of study showed that the fertilizer formula treatment had a very significant effect on organic- $\mathrm{C}(\mathrm{P}<0,01)$ and significantly affected the plant fresh weight $(\mathrm{P}<0,05)$, but had no significant effect on the acidity $(\mathrm{pH})$, total-N, available-K, available-P, cation exchange capacity, base saturation, plant height, number of leaves, and plant dry weight. The $\mathrm{P} 4$ fertilizer formula gave the highest increase in soil organic-C content significantly by $2.99 \%$ or an increase of $66 \%$ compared to the control and gave the highest yield of fresh greens mustard by 23.64 tons ha $^{-1}$.
\end{abstract}

Keywords: fertilizer formula, soil chemical properties, green mustard, subak 


\section{MADE KRISNANDA ADI SAPUTRA. et al. Pengaruh Beberapa Formula Pupuk...}

\section{PENDAHULUAN}

Sawi hijau merupakan salah satu komoditas sayuran yang sangat potensial untuk dibudidayakan karena memiliki nilai ekonomis dan digemari oleh masyarakat Indonesia. Berda-sarkan data Badan Pusat Statistik Provinsi Bali (2017) bahwa produksi tanaman sawi di Provinsi Bali berfluktuasi. Pada tahun 2014 produksi sawi mencapai 30.780,90 ton, namun pada tahun 2015 terjadi penurunan produksi menjadi 26.602,50 ton, sedangkan pada tahun 2016 produksi justru mengalami peningkatan menjadi 29.567 ton. Rata-rata produksi tanaman sawi hijau di Provinsi Bali pada setiap tahunnya cenderung tidak stabil. Ketidakstabilan produksi ini bisa disebabkan oleh beberapa faktor, seperti luas tanam yang bervariasi setiap tahunnya, atau terganggunya keseimbangan hara di dalam tanah. Pengelolaan hara yang tidak berimbang bisa menurunkan hasil tanaman hingga $40 \%$ (Setyorini dkk, 2000).

Indeks Penanaman (IP) tana-man padi di Kecamatan Denpasar Barat tahun 2015, sebesar 219,52. Ini mengindikasikan bahwa pada lahan sawah tersebut rata-rata 2(dua) kali ditanami padi dalam setahunnya. Hal ini sudah tentu dibarengi oleh peng-gunaan pupuk anorganik yang semakin meningkat (Statistik Tana-man Pangan Kota Denpasar, 2015). Penggunaan pupuk anorganik secara intensif bisa menyebabkan terkuras-nya atau menurunnya kandungan bahan organik tanah. Pada lahan sawah di pulau Jawa, ada indikasi terjadinya pelandain peningkatan produksi gabah atau (levelling off), meskipun jumlah pupuk anorganik yang diberikan semakin bertambah, seperti yang dilaporkan (Adiningsih, 1992). Kondisi ini bila dibiarkan akan dapat mengancam ketahanan pangan.

Berdasarkan data analisis tanah awal di lahan sawah Subak Tegal Lantang diperoleh kandungan C-organik tanahnya sebesar 2,98\% termasuk dalam kategori sedang dan kandungan $\mathrm{N}$-total sebesar $0,15 \%$ termasuk dalam kategori rendah. Selain itu, tanah lokasi penelitian memiliki ordo vertisol yang didomi-nasi tipe liat 2:1 yang bersifat vertikehingga mengakibatkan saat musim kemarau tanah menjadi sangat keras dan di musim hujan tanah sangat berat untuk diolah karena drainase yang terhambat.

Salah satu upaya untuk meningkatkan produksi tanaman, produktivitas tanah serta efisiensi penggunaan pupuk adalah penerapan teknologi yang ramah lingkungan melalui sistem pengelolaan hara terpadu (Integrated Plant Nutrient Management System), yaitu mene-rapkan pemupukan berimbang yang dipadukan dengan penggunaan pupuk organik dan hayati yang dikemas dalam suatu formula pupuk. Formula pupuk yang dimaksud adalah 
komposisi bahan-bahan pupuk yang terdiri dari pupuk organik, anorganik, dan hayati yang telah dirancang untuk diterapkan pertama kalinya di lahan sawah Subak Tegal Lantang.

Terkait uraian di atas, maka perlu dilakukan uji formula pupuk untuk mengetahui pengaruhnya terhadap sifat kimia tanah dan peningkatan hasil sawi hijau sebelum direkomendasikan kepada petani, sehingga degradasi tanah dapat diminimalisir atau dicegah demi keberlanjutan pertanian. Tujuan pene-litian ini adalah untuk mengetahui pengaruh formula pupuk yang dicobakan terhadap perubahan sifat kimia tanah dan peningkatan hasil sawi hijau di Subak Tegal Lantang, Desa Padangsambian Kelod, Keca-matan Denpasar Barat.

\section{BAHAN DAN METODE}

Kegiatan penelitian ini dilaksanakan di dua tempat yaitu di Subak Tegal Lantang, Desa Padangsambian Kelod, Kecamatan Denpasar Barat dan untuk analisis tanah dilakukan di Laboratorium Ilmu Tanah Fakultas Pertanian Universitas Udayana. Penelitian dilaksanakan mulai November 2018 sampai dengan Maret 2019.

Bahan-bahan yang digunakan dalam penelitian ini adalah benih sawi hijau (Brassica juncea L.), pupuk organic (kompos
Putri Amerta Jaya), pupuk anorganik (Phonska 15:15:15 dan Urea 46\%), pupuk hayati (Maxigrow), zat-zat kimia untuk analisis tanah dan sampel tanah di lokasi penelitian.

Penelitian ini menggunakan Rancangan Acak Kelompok (RAK) yang terdiri dari 6 perlakuan termasuk kontrol dan diulang 4 kali sehingga didapatkan 24 petak perlakuan. Formula pupuk adalah komposisi bahanbahan pupuk yang terdiri dari pupuk organik, anorganik, dan hayati yang diberikan ke dalam tanah sebagai perlakuan.

Formula pupuk yang dicobakan sebagai berikut:

$\mathrm{P} 0=$ kontrol (tanpa pupuk)

$\mathrm{P} 1=5$ ton kompos ha ${ }^{-1}(3 \mathrm{~kg} /$ petak $)+300 \mathrm{~kg}$

Phonska ha ${ }^{-1}(0,180 \mathrm{~kg} /$ petak $)+200 \mathrm{~kg}$ Urea ha $^{-1}(0,120 \mathrm{~kg} /$ petak $)$

$\mathrm{P} 2=5$ ton kompos ha ${ }^{-1}(3 \mathrm{~kg} /$ petak $)+300 \mathrm{~kg}$

Phonska ha $^{-1}(0,180 \mathrm{~kg} /$ petak $)+200 \mathrm{~kg}$ Urea ha $^{-1}(0,120 \mathrm{~kg} /$ petak $)+$ pupuk hayati (10 cc/liter air/petak)

$\mathrm{P} 3=10$ ton kompos ha ${ }^{-1}(6 \mathrm{~kg} /$ petak $)+300 \mathrm{~kg}$

Phonska ha ${ }^{-1}(0,180 \mathrm{~kg} /$ petak $)+200 \mathrm{~kg}$ Urea ha $^{-1}(0,120 \mathrm{~kg} /$ petak $)$

$\mathrm{P} 4=10$ ton kompos ha ${ }^{-1}(6 \mathrm{~kg} /$ petak $)+300 \mathrm{~kg}$

Phonska ha ${ }^{-1}(0,180 \mathrm{~kg} /$ petak $)+200 \mathrm{~kg}$ Urea ha $^{-1}(0,120 \mathrm{~kg} /$ petak $)+$ pupuk hayati (10 cc/liter air/petak)

P5 = pupuk hayati dengan konsentrasi 10 cc/liter air/petak

Tahapan pelaksanaan penelitian meliputi penyiapan lahan, pembibit-an, 


\section{MADE KRISNANDA ADI SAPUTRA. et al. Pengaruh Beberapa Formula Pupuk...}

penanaman, pemupukan, pemeli-haraan Parameter pertumbuhan tanaman yang diukur tanaman, dan panen. Pemumeliputi: tinggi tanaman, jumlah daun, berat pukan dilakukan sesuai dosis perla-kuan formula pupuk yang telah ditentukan dengan menggunakan pupuk kompos, pupuk Phonska, pupuk Urea dan pupuk hayati. Pupuk kompos diaplikasikan satu minggu sebelum penanaman bibit dengan cara disebar merata disetiap petaknya sesuai dosis yang telah ditentukan untuk setiap perlakuannya.

Pupuk Phonska dan Urea diberikan pada umur 10 hst pada pagi hari dengan cara disebar disekitar perakaran tanaman. Pupuk hayati diaplikasikan 3 kali selama masa pertumbuhan tanaman yaitu pada umur 7, 14, dan 21 hst. Pemberian pupuk hayati dilakukan pada sore hari. Aplikasi pupuk hayati dilakukan dengan cara disemprotkan pada tanah disekitar perakaran tanaman.

Parameter sifat kimia tanah yang dianalisis di laboratorium meliputi $\mathrm{pH}$ tanah ( $\left.\mathrm{H}_{2} \mathrm{O} 1: 2,5\right), \mathrm{N}$-total (Kjeldahl), P-tersedia dan K-tersedia (Bray1), C-organik (Walkley and Black), KTK dan $\mathrm{KB}\left(\mathrm{NH}_{4} \mathrm{Oac} 1 \mathrm{~N}, \mathrm{pH} 7\right)$. segar tanaman, dan berat kering tanaman.

Data yang diperoleh selanjut-nya dianalisis menggunakan sidik ragam (Anova) untuk mengetahui nyata tidaknya perlakuan. Apabila perlakuan berpengaruh nyata terhadap parameter yang diamati, maka dilanjutkan dengan uji BNT pada taraf uji 5\% untuk melihat perbedaan antar masing-masing perlakuan.

\section{HASIL DAN PEMBAHASAN}

Berdasarkan hasil analisis statistik menunjukkan bahwa aplikasi formula pupuk berpengaruh sangat nyata terhadap kandungan C-organik tanah $(\mathrm{P}<0,01)$, tetapi berpengaruh tidak nyata terhadap parameter sifat kimia tanah lainnya. Pengaruh perlakuan pada parameter pertumbuhan dan hasil tanaman juga tidak nyata, kecuali pada berat segar tanaman $(\mathrm{P}<0,05)$ seperti disajikan pada Tabel 1. 
Tabel 1. Perbedaan Pengaruh Formula Pupuk Terhadap Parameter Sifat Kimia Tanah dan Hasil Tanaman Sawi Hijau Saat Panen

\begin{tabular}{clc}
\hline No & Parameter Pengamatan & Perlakuan \\
\hline 1 & $\mathrm{~N}-$ Total $(\%)$ & $\mathrm{Ns}$ \\
2 & $\mathrm{P}-$ Tersedia $(\mathrm{ppm})$ & $\mathrm{Ns}$ \\
3 & $\mathrm{~K}-$ Tersedia $(\mathrm{me} / 100 \mathrm{~g})$ & $\mathrm{Ns}$ \\
4 & $\mathrm{C}-$ Organik $(\%)$ & $* *$ \\
5 & KTK $($ me $/ 100 \mathrm{~g})$ & $\mathrm{Ns}$ \\
6 & KB $(\%)$ & $\mathrm{Ns}$ \\
7 & Derajat Keasaman $(\mathrm{pH})$ & $\mathrm{Ns}$ \\
8 & Tinggi Tanaman $(\mathrm{cm})$ & $\mathrm{Ns}$ \\
9 & Jumlah Daun (helai) & $\mathrm{Ns}$ \\
10 & Berat Segar Tanaman $(\mathrm{g})$ & $*$ \\
11 & Berat Kering Tanaman $(\mathrm{g})$ & $\mathrm{Ns}$ \\
\hline Keterangan: & ns $\quad$ berpengaruh tidak nyata $(\mathrm{P}>0,05)$ & \\
& $* \quad:$ berpengaruh nyata $(\mathrm{P}<0,05)$ &
\end{tabular}

Hasil Analisis Sifat Kimia Tanah

Hasil uji lanjut BNT 5\% pengaruh dibandingkan formula pupuk lainnya dan formula pupuk terhadap nilai rata rata analisis tanah awal. Perlakuan formula pupuk parameter sifat kimia tanah disajikan pada Tabel 2.

\section{C-organik Tanah}

Data hasil uji lanjut BNT 5\% penambahan pupuk organik (kompos) ke menunjukkan bahwa perlakuan formula dalam tanah sehingga kandungan C-organik pupuk P4 memberikan kandungan C-organik tanah meningkat.

Tabel 2. Pengaruh Formula Pupuk terhadap Parameter Sifat Kimia Tanah

\begin{tabular}{cccccccc}
\hline Perlakuan & $\mathrm{pH}$ & $\begin{array}{c}\text { C-organik } \\
(\%) * *\end{array}$ & $\begin{array}{c}\text { N-total } \\
(\%)\end{array}$ & $\begin{array}{c}\text { P-tersedia } \\
(\mathrm{ppm})\end{array}$ & $\begin{array}{c}\text { K- } \\
\text { tersedia } \\
(\mathrm{me} / 100 \mathrm{~g})\end{array}$ & $\begin{array}{c}\text { KTK } \\
(\mathrm{me} / 100 \mathrm{~g})\end{array}$ & $\begin{array}{c}\text { KB } \\
(\%)\end{array}$ \\
\hline P0 & $6,68 \mathrm{a}$ & $2,33 \mathrm{~b}$ & $0,15 \mathrm{a}$ & $38,38 \mathrm{a}$ & $1,01 \mathrm{a}$ & $45,46 \mathrm{a}$ & $96,96 \mathrm{a}$ \\
P1 & $6,68 \mathrm{a}$ & $2,11 \mathrm{~b}$ & $0,23 \mathrm{a}$ & $37,64 \mathrm{a}$ & $0,99 \mathrm{a}$ & $46,58 \mathrm{a}$ & $84,17 \mathrm{a}$ \\
P2 & $6,67 \mathrm{a}$ & $2,45 \mathrm{bc}$ & $0,20 \mathrm{a}$ & $43,26 \mathrm{a}$ & $1,11 \mathrm{a}$ & $45,61 \mathrm{a}$ & $86,58 \mathrm{a}$ \\
P3 & $6,65 \mathrm{a}$ & $2,68 \mathrm{c}$ & $0,18 \mathrm{a}$ & $40,38 \mathrm{a}$ & $1,07 \mathrm{a}$ & $45,55 \mathrm{a}$ & $89,55 \mathrm{a}$ \\
P4 & $6,70 \mathrm{a}$ & $2,99 \mathrm{c}$ & $0,21 \mathrm{a}$ & $45,02 \mathrm{a}$ & $0,97 \mathrm{a}$ & $45,52 \mathrm{a}$ & $95,40 \mathrm{a}$ \\
P5 & $6,73 \mathrm{a}$ & $1,22 \mathrm{a}$ & $0,19 \mathrm{a}$ & $42,99 \mathrm{a}$ & $1,10 \mathrm{a}$ & $45,46 \mathrm{a}$ & $92,95 \mathrm{a}$ \\
\hline BNT 5\% & \multicolumn{7}{c}{0,54} \\
\hline
\end{tabular}

Keterangan: Nilai rata-rata yang diikuti oleh huruf yang sama pada kolom yang sama menunjukkan berbeda tidak nyata pada uji BNT taraf $5 \%$. 


\section{MADE KRISNANDA ADI SAPUTRA. et al. Pengaruh Beberapa Formula Pupuk...}

Pemberian pupuk kompos diperlukan untuk mempertahankan dan meningkatkan kandungan C-organik dalam tanah. Selain itu penambahan pupuk Urea sebagai sumber $\mathrm{N}$ dapat dijadikan sebagai sumber energi bagi aktivitas mikroorganisme, sehingga dengan semakin meningkatnya jumlah $\mathrm{N}$ yang diberikan, semakin meningkat aktivitas dari mikroorganisme dalam merombak senyawa organik menjadi senyawa anorganik sehingga kandungan C-organik menurun. Perlakuan P4 (10 ton kompos ha-1 $+300 \mathrm{~kg}$ Phonska ha ${ }^{-1}+$ $200 \mathrm{~kg}$ Urea ha ${ }^{-1}+$ pupuk hayati 1 cc/liter air/petak) menunjukkan nilai rata-rata $\mathrm{C}$ organik tertinggi sebesar 2,99\%. Formula pupuk P5 memberikan kandungan C-organik tanah yang lebih rendah dibandingkan dengan perlakuan formula pupuk lainnya, hal ini disebabkan tidak adanya pemberian pupuk kompos. Pernya-taan tersebut didukung dengan hasil penelitian Syukur dan Indah (2006) yang mendapatkan bahwa aplikasi pupuk kompos dan pupuk kandang dapat meningkatkan kandungan C-organik tanah.

\section{N-total Tanah}

Nilai rata-rata $\mathrm{N}$-total tanah akibat perlakuan formula pupuk menunjukkan adanya kecenderungan peningkatan dibandingkan dengan kontrol, tetapi secara uji BNT 5\% perbedaan tersebut tidak nyata
(Tabel 2). Kecenderungan peningkatan kandungan $\mathrm{N}$-total tanah tersebut terdapat pada P1 yaitu sebesar 0,23\% (meningkatkan kriterianya menjadi sedang). Pengaruh perlakuan formula pupuk memiliki nilai $\mathrm{N}$ total berkisar antara 0,18 - 0,23\% dengan kriteria rendah sampai sedang. Perlakuan formula pupuk P1, P2, P3, P4 dan P5 memberikan nilai rata-rata kandung-an $\mathrm{N}$ total yang lebih tinggi diban-dingkan P0 (kontrol). Hal ini kemungkinan bisa disebabkan karena aplikasi dosis dari pupuk Urea pada masing-masing formula pupuk tersebut belum tepat dan hanya diberikan satu kali untuk tanah Vertisol di Subak Tegal Lantang, Kecamatan Denpasar Barat. Dengan adanya penambahan pupuk kompos pada masing-masing formula pupuk kecuali P5, maka akan meningkatkan kapasitas jerapan tanah tersebut sehingga nitrogen dalam bentuk ammonium $\left(\mathrm{NH}_{4}{ }^{+}\right)$akan lebih banyak dijerap oleh tanah sedangkan dalam bentuk amoniak $\left(\mathrm{NH}_{3}\right)$ yang berwujud gas mudah menguap hilang dari tanah. Kemungkinan lainnya, terjadinya kontaminasi antar perlakuan yang disebabkan drainase yang buruk menyebabkan nitrogen dalam bentuk nitrat $\left(\mathrm{NO}_{3}{ }^{-}\right)$mudah tercuci sehingga berpengaruh tidak nyata. Peningkatan nilai Ntotal tanah ini diduga berasal dari mineralisasi bahan organik yang diberikan. Menurut 
Setiawan (2000), perubahan kandungan Ntotal tanah boleh jadi terkait dengan meningkatnya bahan organik dari sangat rendah menjadi rendah akibat perlakuan imbangan pemberian pupuk organik dan anorganik yang diberikan. Selain itu, pemberian pupuk Urea ( $\mathrm{N} 46 \%$ ) dengan dosis $200 \mathrm{~kg} \mathrm{ha}^{-1}$ dan Phonska (N 15\%) dengan dosis $300 \mathrm{~kg}$ ha 1 ditengarai mampu meningkatkan kandungan N-total dalam tanah.

\section{P-tersedia Tanah}

Perlakuan formula pupuk memiliki kecenderung meningkatan kandungan Ptersedia tanah disban-dingkan kontrol. Hal ini disebabkan karena pada adanya penambahan pupuk Phonska yang mengandung unsur fosfor (P 15\%) pada formula pupuk P1, P2, P3, dan P4 sehingga akan meningkatkan kandungan $\mathrm{P}$ dalam tanah, kecuali P1 yang mengalami penurunan dibandingkan kontrol. Hasil P-tersedia tanah tertinggi terdapat pada formula pupuk P4 sebesar 45,02 ppm. Sedangkan hasil terendah terdapat pada P1 sebesar 37,64 ppm. Penyebab perlakuan formula pupuk tidak memberikan pengaruh yang nyata diduga karena kandungan $\mathrm{P}$ dalam tanah di Subak Tegal Lantang yang termasuk dalam kategori sangat tinggi sebesar 53,12 ppm.

\section{K-tersedia Tanah}

Perlakuan formula pupuk secara uji BNT menunjukkan hasil yang berbeda tidak nyata (Tabel 2). Formula pupuk P2 memberikan nilai K-tersedia tertinggi dibandingkan formula pupuk lainnya yaitu sebesar $1,11 \mathrm{me} / 100 \mathrm{~g}$ dan termasuk kriteria sangat tinggi dan nilai terendah terdapat pada P4 sebesar 0,97 me/100g. Hal ini mengindikasikan bahwa aplikasi formula pupuk tidak memberikan reaksi yang cukup baik karena unsur $\mathrm{K}$ sudah cukup tersedia di dalam tanah yang terlihat dari analisis tanah awal yang termasuk kategori sedang dengan nilai $0,31 \mathrm{me} / 100 \mathrm{~g}$.. Selain itu, pemberian pupuk Phonska pada formula pupuk P1, P2, P3 dan P4 dapat meningkatkan K-tersedia tanah karena sifat dari pupuk Phonska yang mudah larut dalam air, sehingga menyebabkan $15 \%$ K2O yang terkandung dalam pupuk ini akan terlarut di dalam tanah dan menghasilkan kation $\mathrm{K}$ dalam larutan tanah.

\section{KTK Tanah}

Kapasitas tukar kation menunjukkan kemampuan koloid tanah dalam menjerap dan mempertukarkan kation-kation di dalam tanah. Semakin tinggi KTK yang dimiliki oleh tanah maka semakin besar pula kemampuan tanah untuk menjerap atau memegang dan 


\section{MADE KRISNANDA ADI SAPUTRA. et al. Pengaruh Beberapa Formula Pupuk...}

mempertukarkan ion-ion positif seperti $\mathrm{K}^{+}$, $\mathrm{Ca}^{2+}, \mathrm{NH}^{+}$. Berdasarkan hasil uji BNT 5\% diketahui bahwa nilai rata-rata KTK tanah masing-masing formula pupuk menunjukkan hasil yang berdeda tidak nyata (Tabel 2). Hal ini disebabkan kandungan KTK tanah awal di Subak Tegal Lantang yang termasuk dalam kategori tinggi dengan nilai 39,43 me/100g. Nilai rata-rata KTK tanah seluruh perlakuan termasuk dalam kategori sangat tinggi (>40 me/100g). Formula pupuk P0 dan P5 menunjukkan nilai rata-rata KTK tanah terendah yaitu sebesar 45,46 me/100g, sedangkan perlakuan P1 menunjukkan nilai tertinggi sebesar 46,58 me/100g. Peningkatan nilai KTK tanah terjadi seiring adanya penambahan pupuk kompos pada perlakuan formula pupuk P1, P2, P3 dan P4. Selain itu juga disebabkan oleh jenis tanah di Subak Tegal Lantang. Tanah Vertisol didominasi oleh fraksi liat yang memiliki kapasitas pertukaran ion dan kapasitas memegang air yang tinggi. Rosmarkam dan Yuwono (2002) menyatakan bahwa bahan organik mempunyai daya jerap kation yang lebih besar dari pada koloid liat, sehingga semakin tinggi kandungan bahan organik suatu tanah semakin tinggi pula KTKnya.

\section{KB Tanah}

Kejenuhan basa adalah perbandingan antara jumlah kation basa yang ditukarkan dengan KTK yang dinyatakan dalam persen. Perlakuan P0 memberikan nilai rata-rata KB tertinggi sebesar 96,96 \% kemudian mengalami penurunan berturut-turut pada formula pupuk P4, P5, P3, P2 dan P1. Hasil terendah terdapat pada formula pupuk P1 sebesar 84,17 \%. Dari data hasil uji BNT 5\% terlihat bahwa aplikasi formula pupuk menunjukkan hasil yang berbeda tidak nyata dan tidak memberikan perubahan yang signifikan karena nilai KB tanah awal yang termasuk dalam kategori sangat tinggi dengan nilai sebesar 133,33\%. Tingginya nilai KB pada semua perlakuan pemupukan disebabkan oleh $\mathrm{pH}$ tanah yang tergolong netral, yang akan berpengaruh terhadap kompleks jerapan yang diisi oleh kation-kation basa seperti $\mathrm{Ca}$, $\mathrm{Mg}, \mathrm{K}$, dan Na yang diperlukan oleh tanaman.

\section{Reaksi (pH) Tanah}

Hasil uji BNT 5\% menunjuk-kan bahwa aplikasi masing-masing formula pupuk berbeda tidak nyata terhadap nilai $\mathrm{pH}$ tanah (Tabel 2). Peningkatan $\mathrm{pH}$ tanah terdapat pada formula pupuk P4 sebesar 6,70 dan P5 menunjukkan nilai tertinggi sebesar 6,73. Sedangkan nilai ter-rendah terdapat pada formula pupuk P3 sebessar 6,65. Nilai $\mathrm{pH}$ 
menunjuk-kan banyaknya konsentrasi ion hidrogen $(\mathrm{H})$ dan ion hidroksida $(\mathrm{OH})$ di dalam tanah. Perlakuan formula pupuk memiliki nilai $\mathrm{pH}$ yang tergolong netral yaitu berkisar antara 6,6 - 6,8. Hal ini berarti ion Hidrogen dan ion Hidroksida yang dihasilkan dalam proses pelapukan bahan organik oleh mikroorganisme tanah adalah relatif seimbang, sehingga $\mathrm{pH}$ tanah menjadi netral (Madjid, 2017).

\section{Pertumbuhan dan Hasil Tanaman Sawi} Hijau

Hasil uji lanjut BNT 5\% pengaruh formula pupuk terhadap nilai rata-rata parameter pertumbuhan dan hasil tanaman sawi hijau disajikan pada Tabel 3.

\section{Tinggi Tanaman}

Aplikasi formula pupuk P1, P2, P3, dan P4 menunjukkan adanya kecenderungan peningkatan terhadap tinggi tanaman dibandingkan dengan P5 dan kontrol. Perlakuan formula pu puk P4 memberikan kecenderungan yang lebih baik, yaitu sebesar $44,18 \mathrm{~cm}$, disebabkan karena formula P4 ini mampu meningkatkan kandungan C-organik tanah. Namun secara uji BNT 5\% menunjukkan perbedaan tidak nyata dibandingkan formula pupuk lainnya (Tabel 3). Diduga hal ini disebabkan karena kebutuhan nitro-gen untuk tanaman sudah cukup tersedia akibat adanya penambahan unsur nitrogen yang berasal dari pupuk Phonska, Urea serta kompos.

Pemberian kompos pada masingmasing formula pupuk kecu-ali P5 mampu mengaktifkan mikro-organisme tanah sehingga proses penghancuran bahan organik berjalan lancar, memperbaiki sifat fisik, kimia dan biologi tanah sehingga kesuburan tanah semakin meningkat. Senyawa-senyawa organik seperti asam humik dan asam fulvat yang terkandung dalam kompos memiliki peranan se-bagai hormon tumbuhan yang dapat merangsang pertumbuhan tanaman. 
MADE KRISNANDA ADI SAPUTRA. et al. Pengaruh Beberapa Formula Pupuk...

Tabel 3. Pengaruh Perlakuan Formula Pupuk terhadap Pertumbuhan dan Hasil Tanaman

\begin{tabular}{cccccc}
\hline Perlakuan & $\begin{array}{c}\text { Tinggi } \\
\text { Tanaman } \\
(\mathrm{cm})\end{array}$ & $\begin{array}{c}\text { Jumlah Daun } \\
\text { (helai) }\end{array}$ & $\begin{array}{c}\text { Berat } \\
\text { Segar } \\
\text { Tanaman } \\
(\mathrm{g})\end{array}$ & $\begin{array}{c}\text { Hasil Sawi } \\
\text { Hijau } \\
(\text { ton/ha) }\end{array}$ & $\begin{array}{c}\text { Berat } \\
\text { Kering } \\
\text { Tanaman } \\
(\mathrm{g})\end{array}$ \\
\hline P0 & $32,33 \mathrm{a}$ & $12,00 \mathrm{a}$ & $112,50 \mathrm{a}$ & $12,50 \mathrm{a}$ & $7,60 \mathrm{a}$ \\
P1 & $34,33 \mathrm{a}$ & $10,75 \mathrm{a}$ & $121,75 \mathrm{a}$ & $13,53 \mathrm{a}$ & $7,93 \mathrm{a}$ \\
P2 & $40,70 \mathrm{a}$ & $12,25 \mathrm{a}$ & $191,75 \mathrm{~b}$ & $21,31 \mathrm{a}$ & $8,29 \mathrm{a}$ \\
P3 & $37,78 \mathrm{a}$ & $12,75 \mathrm{a}$ & $193,25 \mathrm{~b}$ & $21,47 \mathrm{a}$ & $8,50 \mathrm{a}$ \\
P4 & $44,18 \mathrm{a}$ & $13,00 \mathrm{a}$ & $212,75 \mathrm{~b}$ & $23,64 \mathrm{a}$ & $9,00 \mathrm{a}$ \\
P5 & $30,53 \mathrm{a}$ & $10,50 \mathrm{a}$ & $101,75 \mathrm{a}$ & $11,28 \mathrm{a}$ & $6,36 \mathrm{a}$ \\
\hline BNT 5\% & & & 49,00 & & \\
\hline
\end{tabular}

Keterangan: Nilai rata-rata yang diikuti oleh huruf yang sama pada kolom yang sama menunjukkan berbeda tidak nyata pada uji BNT taraf 5\%.

\section{Jumlah Daun}

Hasil uji BNT 5\% pengaruh perlakuan formula pupuk terhadap jumlah daun menunjukkan hasil yang berbeda tidak nyata (Tabel 3). Pengaruh yang berbeda tidak nyata dari berbagai perlakuan formula pupuk diduga disebabkan oleh pengaruh genetik lebih dominan terhadap parameter jumlah daun. Pengaruh genetik yang kuat membuat pertumbuhan daun menjadi kurang jelas (Martoyo, 2001). Perlakuan formula pupuk P2, P3 dan P4 cenderung meningkatkan rata-rata jumlah daun tanaman sawi hijau lebih baik dibandingkan formula pupuk P1, P5 dan kontrol. Perlakuan formula pupuk P4 mampu memberikan nilai rata-rata jumlah daun sebesar 13,00 helai, namun rataan jumlah daun tersebut berbeda tidak nyata dengan rataan jumlah daun pada formula pupuk lainnya. Perlakuan formula pupuk memberikan kisaran rata-rata jumlah daun antara 10,50 - 13,00 helai. Perlakuan formula pupuk pada penelitian ini ternyata belum mem-berikan pengaruh yang bermakna terhadap peningkatan jumlah daun tanaman sawi hijau.

\section{Berat Segar Tanaman}

Hasil uji lanjut BNT5 \% menunjukkan bahwa nilai rata-rata berat segar tanaman pada perlakuan formula pupuk P2, P3 dan P4 berbeda nyata dibandingkan perlakuan lainnya. Meningkatnya berat segar tanaman disebabkan kebutuhan $\mathrm{N}$ pada fase vegetatif tanaman telah tercukupi, sehingga meningkatkan biomassa tanaman. Pemberian pupuk anorganik Phonska dan Urea berperan dalam menyediakan unsur 
hara yang tersedia bagi tanaman dengan kandungan yang tinggi dan relatif cepat diserap. Berdasarkan hasil penelitian Subagyo (2007) perlakuan dengan dosis pupuk Urea $250 \mathrm{~kg} \mathrm{ha}^{-1}$ memberikan pertumbuhan terbaik pada parameter tinggi tanaman, jumlah daun dan hasil sawi yang terbaik.

Perlakuan formula pupuk P4 menunjukkan nilai rata-rata berat segar tanaman tertinggi yaitu sebesar 212,75 g atau hasil sebesar 23,64 ton ha-1. Adanya penambahan pupuk kompos dan kombinasinya pada formula pupuk P1, P2, P3 dan P4 menyebabkan tingginya hasil tanaman dibandingkan formula pupuk P5 dan kontrol. Aplikasi pupuk kompos berperan dalam menyediakan unsur hara $\mathrm{N}$, $\mathrm{P}$, dan $\mathrm{K}$ yang dibutuhkan tanaman sawi hijau dan mendukung proses fisiologi dan biokimia seperti respirasi akar, permeabilitas tanah dan penyerapan air sehingga akan meningkatkan kadar $\mathrm{C}, \mathrm{H}, \mathrm{O}$ dan kadar air yang merupakan komponen utama dalam penyusunan biomassa tanaman. Selain itu, juga disebabkan pada formula pupuk P1, P2, P3 dan P4, tanaman sawi menghasilkan rata-rata tinggi tanaman dan jumlah daun pertanaman yang cenderung lebih tinggi dibandingkan perlakuan for-mula pupuk lainnya.
Berat segar tanaman terendah terdapat pada formula pupuk P5 sebesar 101,75 $\mathrm{g}$ atau hasil sebesar 11,28 ton $\mathrm{ha}^{-1}$. Penyebab pengaruh yang ber-beda tidak nyata antara formula pupuk P5 dan kontrol diduga karena kenungkinan rendahnya aktivitas mikroorganisme dalam pupuk hayati yang digunakan. Aktivitas mikroorganisme dalam pupuk hayati, antara lain dipengaruhi oleh tingkat keterse-diaan $\mathrm{C}$ organik tanah dan kemam-puannya membentuk koloni serta bersaing dengan mikroba lokal. Aktivitas penambatan $\mathrm{N}_{2}$ oleh mikro-organisme bergantung pada kemam-puan bersaing dengan mikroorganisme lainnya (Setiawati, 2014).

Perlakuan formula pupuk P4 memberikan hasil yang tertinggi dalam setiap variabel pertumbuhan tanaman dan hasil tanaman sawi hijau dibandingkan formula pupuk lainnya (Tabel 3). Hal ini dapat dimengerti karena semakin bertambahnya tinggi tanaman dan jumlah daun maka semakin banyak asimilat yang dihasilkan tanaman sehingga pada akhirnya semakin tinggi berat segar tanaman yang dihasilkan.

\section{Berat Kering Tanaman}

Pengaruh perlakuan formula pupuk terhadap berat kering tanaman secara uji 
MADE KRISNANDA ADI SAPUTRA. et al. Pengaruh Beberapa Formula Pupuk...

BNT menunjukkan hasil yang berbeda tidak nyata (Tabel 3). Nilai rata-rata berat kering tanaman tertinggi terdapat pada formula pupuk P4 sebesar 9,00 g dan nilai terendah terdapat pada formula pupuk P5 sebesar 6,36 g. Pertumbuhan tanam-an merupakan fungsi dari keefisien-annya dalam memproduksi bahan kering tanaman. Berat kering erat hubungannya dengan meningkatnya pertumbuhan dan perkembangan dalam menyerap hara untuk pertumbuhan dan perkembangan bagian vegetatif. Berat kering suatu tanaman merupakan hasil penum-pukan fotosintat yang dalam pemben-tukannya membutuhkan unsur hara, air, $\mathrm{CO}_{2}$ dan cahaya matahari.

\section{SIMPULAN}

Formula pupuk P4 (10 ton kompos $\mathrm{ha}^{-1}+300 \mathrm{~kg}$ Phonska ha ${ }^{-1}+200 \mathrm{~kg}$ Urea ha $1+10$ cc pupuk hayati/liter air/petak) memberikan peningkatan tertinggi pada kandung-an C-organik tanah secara bermakna sebesar 2,99\% atau peningkatan sebesar $66 \%$ dibandingkan kontrol. dan membe-rikan hasil berat segar tanaman sawi hijau tertinggi sebesar 23,64 ton ha ${ }^{-1}$ atau peningkatan hasil sebesar 89,12\% dibandingkan kontrol. Dosis formula pupuk pada perlakuan P2 (5 ton kompos ha ${ }^{-1}+$ 300kg Phonska ha ${ }^{-1}+200 \mathrm{~kg}$ Urea ha ${ }^{-1}+10$ cc pupuk hayati/liter air/petak) dapat digunakan sebagai acuan meningkatkan sifat kimia tanah dan hasil tanaman sawi hijau pada tanah Vertisol. Penggunaan konsentrasi pupuk hayati Maxigrow perlu ditingkatkan sesuai dengan anjuran.

\section{DAFTAR PUSTAKA}

Badan Pusat Statistik Provinsi Bali. (2017). Statistik Dasar Hortikultura,https://bali.bps.go.id /dynamictable/2017/05/18/155/produ ksi-petsai-sawi-provinsi-balimenurut kabu-paten-kota-20002017.html (diakses 20 Mei 2019).

Madjid, A. (2017). Kemasaman Tanah. http://distan.buleleng.go.id. Diakses pada tanggal 7 Mei 2019.

Martoyo, K. (2001). Sifat Fisik Tanah Ultisol Pada Penyebaran Akar Tanaman Kelapa Sawit.Warta.PPKS

Rosmarkam, A dan H. W. Yuwono., (2002). Ilmu Kesuburan Tanah. Kanisius. Jakarta.

Setiawati, M. R. (2014). Peningkatan Kandungan $N$ dan $P$ Tanah serta Hasil Padi Sawah Akibat Aplikasi Azolla Pinnata dan Pupuk Hayati Azotobacter Chroococcum dan Pseudo-monas cepaceae. Agrologia, 3 (1): 61-74. Issn. 2301-7287

Setyorini, D., L.R. Widowati, and W. Hartatik. (2000). Organic Fertilizer Characteristic by Composting Technique for Organic Farming Cultivation. InProceeding IX HITI (Soil Science Society of Indonesia), Yogyakarta.

Adiningsih, S. J. (1992). Peranan Efisiensi Penggunaan Pupuk Untuk Melestarikan Swasem-bada Pangan. Orasi Pengu-kuhan Ahli Peneliti Utama. Badan Litbang Pertanian, Deptan. 
AGROTROP, 10 (2): 110 - 122 (2020)

Setiawan, A. I. (2000). Memanfaatkan Kotoran Ternak. Penebar Swadaya. Jakarta.

Statistik Tanaman Pangan Kota Denpasar. (2015). https://Denpasarkota.bps.go.id/publication/2016 /09/26/345346d3a9b9cea0219ab2fe/s tatistik-tanam-anpa-ngan-kotadenpasar-2015.html (Diakses 5 April 2020).

Subagyo. (2007). Sawi, Nitrogen, Pupuk. Skripsi Fakultas Per-tanian Universitas Brawijaya Malang.

Syukur, A. dan N. M. Indah. (2006). Kajian Pengaruh Pemberian Pupuk Organik Terhadap Pertumbuhan dan Hasil Tanaman Jahe di Inceptisol, Karanganyar. J. Ilmu Tanah dan Lingkungan Vol. 6 No. 2. 